\title{
Laporan Kasus: Infeksi Cacing Oxyuris spp. pada Iguana Hijau (Iguana iguana)
}

\author{
Case Report: Oxyuris spp. Infection on Green Iguana (Iguana iguana) \\ Vivi Oktaviana ${ }^{1 *}$, Aditya Yudhana ${ }^{2}$, Nadya Amanda ${ }^{1}$ \\ ${ }^{1}$ Pendidikan Profesi Dokter Hewan, \\ ${ }^{2}$ Departemen Parasitologi, \\ Fakultas Kedokteran Hewan PSDKU Banyuwangi, Universitas Airlangga, \\ Jl. Wijaya Kusuma No.113, Mojopanggung, Giri, Banyuwangi \\ *Corresponding author: voktaviana355@ gmail.com
}

\begin{abstract}
Abstrak
Iguana hijau (Iguana iguana) merupakan hewan eksotik yang dewasa ini banyak dipelihara oleh masyarakat. Pengetahuan masyarakat terkait pemeliharaan iguana masih sangat minim sehingga menimbulkan berbagai masalah kesehatan, salah satunya adalah infeksi parasit cacing gastrointestinal. Iguana hijau berumur 2 tahun yang dimanfaatkan sebagai hewan peliharaan di Banyuwangi, Jawa Timur diduga menderita helmintiasis dengan gejala klinis seperti emasiasi dan diare. Laporan kasus ini bertujuan untuk mendeteksi kejadian helmintiasis pada iguana hijau yang dipelihara dan dimanfaatkan dengan tujuan sebagai hewan eksotik. Feses yang berasal dari iguana hijau dilakukan pemeriksaan menggunakan metode natif, sedimentasi dan apung. Berdasarkan hasil pemeriksaan berhasil ditemukan telur cacing Oxyuris spp. Studi ini merupakan laporan kasus pertama di Indonesia terkait dengan infeksi cacing Oxyuris spp. pada iguana hijau.
\end{abstract}

Kata kunci: Helmintiasis, Iguana iguana, Oxyuris spp.

\section{Abstract}

Green iguana (Iguana iguana) is exotic animal that nowadays keep as pet. The lack of information regarding management on iguana can cause various problems, such as infectious disease which caused by gastrointestinal parasite. A two years old green iguana which kept as pet in Banyuwangi East Java suspected with helminthiasis with clinical signs such as emasiation and dhiarrhea. This study aims to briefly report the occurrence of helminthiasis in green iguana which kept as pet. Fecal samples from green iguana was examined using the native, sedimentation and floating methods. The results on fecal examination was found worms parasite eggs which dominated by Oxyuris spp. This study is the first case report in Indonesia related to Oxyuris spp worm infection on green iguanas.

Key words: Helminthiasis, Iguana iguana, Oxyuris spp.

Received: 6 Maret 2019

Revised: 10 April 2019

Accepted: 8 Juli 2019

\section{PENDAHULUAN}

Reptil saat ini mulai banyak diminati masyarakat sebagai hewan peliharaan eksotik. Jenis reptil yang sering dijadikan hewan peliharaan antara lain ular, kura-kura dan berbagai jenis kadal. Kadal merupakan reptil yang memiliki jumlah spesies paling banyak yakni sekitar 4450 spesies yang mendiami berbagai tipe habitat (Ekici et al., 2011). Hewan ini mulai dikenal dan dijadikan sebagai hewan peliharaan karena perawatannya yang mudah.
Salah satu kadal yang dipelihara oleh masyarakat Indonesia adalah iguana hijau (Iguana iguana) yang termasuk dalam anggota famili Iguanidae dan tergolong reptil herbivora (Nurjunitar, 2016).

Iguana hijau memiliki tubuh besar dan merupakan hewan semi-arboreal sampai arboreal. Iguana hijau memiliki ekor yang relatif panjang (hingga tiga kali panjang tubuh) dan gelambir permanen. Spesies iguana memiliki satu atau lebih sisik besar di bawah gendang telinga dan jengger yang besar di area nuchal 
serta puncak punggung belakang. Jantan dan betina memiliki satu baris pori-pori femoralis di bawah paha. Kaki iguana relatif pendek tetapi kuat dan memiliki cakar yang tajam sebagai alat penggali dan pemanjat. Iguana merupakan kadal yang pandai berenang dan memanjat, kebiasaan tersebut digunakan untuk melindungi diri dari predator yang akan memangsa mereka (Vosjoli et al., 2012).

Status konservasi iguana hijau adalah dinyatakan least concern oleh IUCN (International Union for Conservation of Nature) dan dikatagorikan dalam Appendix II oleh CITES (Convention on International Trade in Endangered Species) (IUCN, 2018; CITES, 2019). Least concern atau beresiko rendah adalah status konservasi yang diberikan kepada spesies yang telah dievaluasi namun tidak masuk ke dalam kategori mengalami kepunahan yang artinya jumlah populasinya masih cenderung stabil. Kategori Appendix II pada CITES menunjukkan bahwa iguana hijau termasuk dalam daftar spesies yang tidak terancam kepunahan, tetapi mungkin terancam punah bila perdagangan terus berlanjut tanpa adanya pengaturan. Meninjau status iguana hijau berdasarkan IUCN dan CITES menyebabkan minat masyarakat untuk menjadikan sebagai hewan peliharaan eksotik semakin meningkat.

Pemeliharaan yang buruk tersebut tidak lepas dari ancaman penyakit, salah satu penyakit yang dapat menyerang iguana hijau adalah infeksi cacing pada saluran gastrointestinal. Cacing parasit gastrointestinal yang dapat menyerang famili Iguanidae antara lain Cestoda, Nematoda dan Trematoda, sementara itu iguana hijau dilaporkan lebih sering terinfeksi Cestoda dan Nematoda (Rataj et al., 2011).

Data mengenai laporan kasus infeksi parasit cacing pada iguana hijau untuk wilayah Indonesia masih sangat sedikit. Informasi mengenai parasit yang menginfeksi iguana hijau dapat dijadikan data dasar sebagai bahan untuk menentukan pengambilan kebijakan perlakuan medis. Studi ini merupakan laporan kasus pertama di Indonesia mengenai infeksi cacing Oxyuris spp. pada iguana hijau. Diharapkan data yang diperoleh dapat digunakan untuk melengkapi data penyakit parasit pada iguana hijau.

\section{METODE PENELITIAN}

Iguana hijau didapatkan dari salah satu pemilik reptil di Kabupaten Banyuwangi Jawa Timur. Berusia sekitar 2 tahun dan berdasarkan anamnesa kepada pemilik mempunyai nafsu makan dan minum yang baik. Riwayat pemeriksaan pada iguana belum pernah dilakukan sebelumnya. Berdasarkan pemeriksaan fisik tidak tampak gejala klinis namun, feses cenderung lembek disertai frekuensi defekasi yang meningkat dan iguana mengalami emasiasi. Diduga iguana hijau menderita helmintiasis sehingga dilakukan pemeriksaan parasitologi untuk mengkonfirmasi.

Pemeriksaan feses dilakukan dengan metode natif, sedimen dan apung. Data yang diperoleh kemudian disajikan secara deskriptif. Identifikasi telur cacing dilakukan di Laboratorium Instrumen Universitas Airlangga PSDKU (Progam Studi Diluar Kampus Utama) Banyuwangi. Metode natif (direct slide) merupakan gold standart pemeriksaan kualitatif tinja karena sensitif, murah, mudah dan pengerjaanya cepat, namun pemeriksaan metode ini kurang sensitif pada infeksi parasit ringan (Regina dkk., 2018). Metode sedimentasi menggunakan larutan dengan berat jenis (BJ) yang lebih rendah dari telur cacing sehingga dapat mengendap di dasar larutan sedangkan metode pengapungan menggunakan larutan dengan BJ yang lebih tinggi dari telur cacing sehingga telur terapung di permukaan larutan.

Langkah kerja yang dilakukan pada metode natif adalah feses diambil menggunakan lidi atau ujung gelas pengaduk yang kecil kemudian dioleskan pada object glass. Air sebanyak 1-2 tetes ditambahkan di atas object glass dan diaduk rata kemudian ditutup dengan cover glass. Preparat natif kemudian diperiksa di bawah mikroskop dengan perbesaran 100x. Hasil negatif dari pemeriksaan metode natif tidak berarti hewan bebas dari peyakit cacing, oleh karena itu diperlukan pemeriksaan feses metode 
sedimen atau apung untuk menunjang diagnosa (Sosiawati dkk., 2017).

Metode sedimentasi yang digunakan dalam pemeriksaan adalah simple sedimentation method. Langkah kerja pertama adalah membuat suspensi feses dengan perbandingan 1 bagian feses dengan 10 bagian air. Suspensi feses kemudian disaring dan filtratnya ditampung dalam Beaker glass. Filtrat kemudian disentrifugasi selama 2-5 menit dengan kecepatan 1500 RPM (Rate Per Minute). Supernatan yang terbentuk dibuang dan ditambahkan air lagi kemudian disentrifugasi dengan waktu dan kecepatan yang sama, ulangi langkah tersebut sampai diperoleh cairan supernatan yang jernih. Supernatan kemudian dibuang dan disisakan sedikit, selanjutnya sedimen diaduk dan diambil secukupnya menggunakan pipet Pasteur untuk diletakkan pada object glass dan ditutup dengan cover glass. Preparat yang sudah siap kemudian diperiksa di bawah mikroskop dengan perbesaran 100x (Sosiawati dkk., 2017).

Metode pengapungan menggunakan bahan tambahan berupa larutan glukosa $80 \%$. Langkah kerja pertama adalah membuat suspensi feses dengan perbandingan 1 bagian feses dengan 10 bagian air. Suspensi feses kemudian disaring dan filtratnya ditampung dalam Beaker glass. Filtrat kemudian disntrifugasi selama 2-5 menit dengan kecepatan 1500 RPM (Rate Per Minute), langkah ini diulangi beberapa kali sampai diperoleh supernatan yang jernih. Supernatan yang terbentuk dibuang dan ditambahkan larutan glukosa $80 \%$ lalu disentrifugasi dengan cara yang sama. Langkah selanjutnya adalah meletakkan cover glass secara perlahan di permukaan tabung sentrifus dan dibiarkan 1-2 menit. Cover glass kemudian diletakkan di atas object glass dan diperiksa di bawah mikroskop dengan perbesaran 100x (Sosiawati dkk., 2017).

\section{HASIL DAN PEMBAHASAN}

Berdasarkan hasil pemeriksaan feses metode natif, sedimentasi maupun apung dari iguana hijau yang diduga terinfeksi cacing parasit (Gambar 1) ditemukan adanya telur cacing
Oxyuris spp. (Gambar 2). Telur cacing ini berbentuk oval asimetris, tumpul pada salah satu bagian sisi dan mempunyai operculum di salah satu ujungnya. Dinding telur tipis dan berwarna transparan (Tiuria dkk., 2017). Ukuran telur Oxyuris bervariatif yakni panjang sekitar 50-60 $\mu \mathrm{m}$ dan lebar 20-32 $\mu \mathrm{m}$ (Bhattacharya et al., 2012), sedangkan ukuran telur yang ditemukan dalam studi kasus ini adalah panjang $57 \mu \mathrm{m}$ dan lebar $31 \mu \mathrm{m}$. Famili oxyuridae merupakan nematoda dengan ventrolateral papillae yang rudimenter. Cacing yang termasuk famili ini berukuran medium sampai kecil, dengan tiga bibir yang tidak menonjol. Esofagusnya mempunyai bangunan semacam bulbus dibagian posteriornya. Panjang cacing jantan antara 9-12 $\mathrm{mm}$ dan cacing betina mencapai $150 \mathrm{~mm}$. Cacing jantan mempunyai satu spikula yang menyerupai jarum dengan panjang 0,12-0,165 $\mu \mathrm{m}$, sedangkan pada ekornya terdapat dua pasang papil. Cacing betina dewasa berwarna abu-abu sampai kecoklatan dengan ekor sempit dan panjang mencapai 3 kali panjang tubuh (Kusnoto dkk., 2010).

Cacing jantan dan betina muda berhabitat pada sekum dan kolon. Setelah fertilisasi, cacing betina dewasa menuju rectum dan berpindah ke daerah kloaka dengan bagian anterior tubuh mengarah ke kloaka. Telur dikeluarkan dan diletakkan dalam bentuk kluster atau gerombolan-gerombolan telur pada kulit daerah perineal. Perkembangan telur menjadi stadium infektif dapat berlangsung dalam waktu 3-5 hari saat berada di daerah kloaka atau sebagian di tanah. Telur kemungkinan tahan beberapa minggu dalam keadaan lembab, namun akan lebih cepat mati pada keadaan kering. Infeksi atau penularan terjadi karena menelan telur infektif pada kandang maupun pakan. Larva infektif terbebas dalam usus halus dan stadium III terbentuk dalam mukosa kolon. Larva stadium IV terbentuk 8-10 hari setelah infeksi terjadi, pada stadium ini cacing memiliki bukal kapsul yang besar dan terbenam dalam mukosa. Alat reproduksi cacing aktif pada stadium dewasa yang dicapai antara 4-5 bulan setelah infeksi (Kusnoto dkk., 2010). 


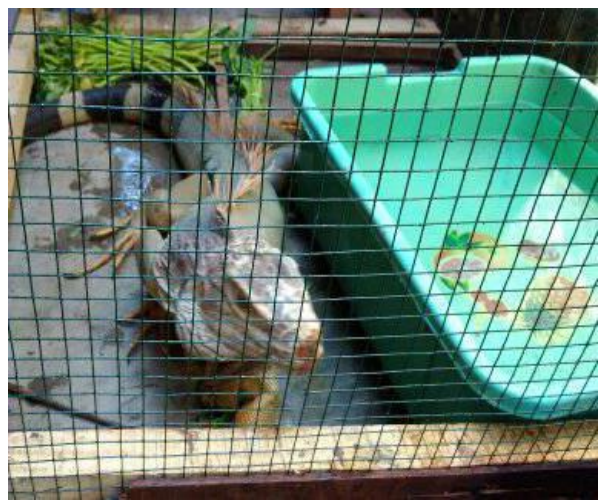

Gambar 1. Iguana hijau (Iguana iguana)

Infeksi cacing Oxyuris spp. sangat umum terjadi pada reptil dan sebagian besar kasus memiliki patogenisitas yang rendah (Wilson and Carpenter, 1996 ; Ippen and Zwart, 1996 ; Rataj et al., 2011). Parasit dalam jumlah sedikit tidak menimbulkan gejala klinis pada hewan. Secara umum regenerasi epitel gastrointestinal terjadi cukup cepat sehingga gejala infeksi parasit tidak tampak. Kasus infeksi yang kronis dimanifestasikan dengan muntah, konsistensi feses cair, kelemahan dan anoreksia (Wilson and Carpenter, 1996). Perubahan konsistensi feses menjadi lebih cair dan memiliki bau yang tidak sedap adalah karakteristik peradangan pada saluran pencernaan. Makanan sering kali tidak tercerna dengan baik meskipun suhu lingkungan optimal (Ras-Norynska and Sokol, 2015). Kondisi pemeliharaan yang buruk dapat menimbulkan stres dan penurunan imunitas. Kondisi kepadatan populasi yang tinggi, buruknya kebersihan kandang, malnutrisi dan manajemen yang buruk dapat memicu parasit bermultiplikasi dengan cepat dan meningkatkan sifat invasif (Hedley, 2013).

Cacing Oxyuris spp. dilaporkan oleh RasNorynska and Sokol (2015) menginfeksi beberapa spesies kadal yang berbeda di Inggris, sebanyak 17 dari 50 ekor Bearded dragon (Pegona viticeps) terinfeksi parasit saluran pencernaan dan salah satunya adalah cacing Oxyuris spp. Jenis kadal lainnya seperti chinese water dragon (Physignathus concinus), veiled chameleon (Chamaeleo calyptratus) dan leopard geckos (Eublepharis macularuis) juga terinfeksi oleh cacing Oxyuris spp. Infeksi cacing Strongyluris brevicaudata dan

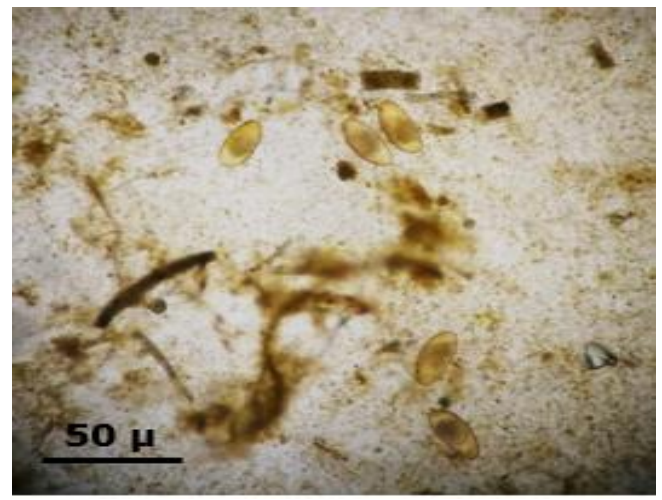

Gambar 2. Telur Oxyuris spp. perbesaran 100x

Parapharyngodon sp. dari filum Nematoda dilaporkan menyerang spesies kadal Agama agama di Nigeria. Cacing dari filum Cestoda (Oochoristica truncate) dan Trematoda (Mesocoelium monas) juga dilaporkan menginfeksi jenis kadal yang sama (Sowemimo and Oluwafemi, 2017).

Menurut laporan Ekici et al. (2011) ditemukan telur cacing nematoda dan cestoda pada sistem pencernaan iguana hijau. Iguana berusia 9 bulan dilakukan pemeriksaan fisik di laboratorium parasitologi. Berdasarkan anamnesa dengan pemilik dapat diketahui bahwa iguana memiliki kondisi kesehatan dan gizi yang buruk. Telur Nematoda (Oxyuris spp.) dan telur Cestoda (Mesocestoides spp.) berhasil didiagnosis dengan pemeriksaan feses metode apung. Rataj et al. (2011) juga telah melakukan pemeriksaan parasit terhadap 331 kadal dengan 15 spesies yang berbeda. Hasil penelitian berhasil mengidentifikasi 8 spesies nematoda, 1 spesies cestoda, 1 spesies trematoda dan 1 spesies Acantocephala. Salah satu jenis kadal yang dilakukan pemeriksaan adalah iguana hijau yang menunjukkan terinfeksi cacing dari kelas Cestoda yakni Oochoristica sp., sedangkan dari kelas Nematoda adalah cacing Physaloptera sp. Pemeriksaan parasitologi juga dilakukan pada 18 Iguana hijau di daerah semi kering timur laut Brazil dan ditemukan adanya infeksi cacing Physaloptera sp., Atractis sp., Piratuba sp. dan Subulura sp. (Teles et al., 2017).

Obat anthelmintik yang dapat digunakan untuk pengobatan pada reptil yang terinfeksi cacing nematoda antara lain levamisole, fenbendazole, piperazine dan ivermectin. 
Kombinasi emodepside dan praziquantel juga telah terbukti efektif (Brames, 2008). Iguana hijau yang terinfeksi cacing perlu dilakukan pengobatan secara medis. Menurut Ekici et al. (2011) iguana hijau yang diterapi dengan ivermectin $(0,2 \mathrm{mg} / \mathrm{kg}$, per oral) dikombinasi dengan praziquantel $(10 \mathrm{mg} / \mathrm{kg}$, sub kutan) menunjukkan hasil yang optimal. Nafsu makan serta keadaan fisik iguana hijau tampak lebih membaik setelah 2 minggu dilakukan pengobatan. Pemeriksaan parasitologis pasca pengobatan dengan anthelmintik dianjurkan untuk memastikan pengobatan yang dilakukan tepat (Machin, 2015).

\section{KESIMPULAN}

Studi kasus ini berhasil mengidentifikasi telur cacing Oxyuris spp. pada iguana hijau. Diperlukan studi lebih lanjut untuk memperjelas sifat biologis dari cacing guna menegakkan penanganan medis. Edukasi terkait penyakit parasit pada hewan eksotik harus diberikan kepada pemilik reptil.

\section{UCAPAN TERIMA KASIH}

Penulis mengucapkan terimakasih kepada Universitas Airlangga PSDKU Banyuwangi atas dukungan fasilitas sehingga kasus ini dapat diselesaikan. Peneliti juga mengucapkan terimakasih kepada tim asisten dosen parasitologi veteriner yang telah bekerjasama sehingga seluruh kegiatan dapat dilaksanakan dengan baik.

\section{DAFTAR PUSTAKA}

Bhattacharya, S., Dutta, B. Mondal, U. Mukherjee, J., Mitra, M. 2012. Helminthiasis in a Bengal Tiger (Panthera tigris tigris). Anim. Med. Res., 2, 184-188.

Brames, H. 2008. Effcacy and Tolerability of Profender in Reptiles: Spot-on Treatment Against Nematodes. Exotic DVM, 10, 2934.
CITES. 2015. Checklist of CITES Species. Diakses 3 Maret 2019 pukul 3.23 WIB pada http://checklist.cites.org.

Ekici, O.D., Isik, N., Guclu, F. 2011. Gastrointestinal Parasites Found in A Green Iguana (Iguana iguana). Eurasian J. Vet. Sci., 27(2), 131-134.

Hedley, J., Eatwell, K., Shaw, D.J. 2013. Gastrointestinal Parasitic Buredens in UK Tortoise: A Survey of Tortoise Owners and Potential Risk Faktor. Vet. Rec., 173(21), 525.

Ippen, R., Zwart, P. 1996 Infectious and Parasitic Disease of Captive Reptiles and Amphibians, with special emphasis on husbandry practices which prevent or promote disease. Scientific and Technical Review of The Office International des Epizooties, 15, 43-54.

IUCN. 2008. The IUCN Red List of Threatened Species. ISSN 2307-8235.

Kusnoto, Koesdarto, S., Bendryman, S.S., Sosiawati, S.M. 2010. Cetakan Pertama. Airlangga University Press, p57-58.

Machin, M.A. 2015. Common Gastrointestinal Parasites in Reptiles. In Practice, 37, 469475.

Nurjuanitar, A.V. 2016. Analisis Perubahan Struktur Anatomi dan Histologi Ginjal Iguana Hijau (Iguana iguana) Setelah Pemberian Pakan Bayam Merah (Amaranthus tricolor L.). [Skripsi]. Fakultas Kedokteran Hewan. Universitas Hasanuddin.

Ras-Norynska, M., Sokol, R. 2015. Internal Parasites of Reptiles. Annals of Parasitol., 61(2), 115-117.

Regina, M.P., Halleyantoro, R., Bakri, S. 2018. Perbandingan Pemeriksaan Tinja Antara Metode Sedimentasi Biasa dan Metode 
Sedimentasi Formol Ether Dalam

Mendeteksi Soil Transmitted Helminth. J.

Kedokteran Diponegoro, 7(2), 527-537.

Sosiawati, S.M., Koesdarto, H.S., Bendryman, S.B., Kusnoto. 2017. Ilmu Penyakit Helminth Veteriner. Airlangga University Press, p8-11.

Sowemimo, O.A., Oluwafemi, T.A. 2017. A Survey of Helminth Parasites of The Lizard, Agama agama in Ile-Ife and Ibadan Southwest Nigeria. J. Bacteriol. Parasitol., 8(1), 1-6.

Teles, D.A., Brito, S.V., Teixeira, A.A.M., Ribeiro, S.C., Araujo-Filho, J.A., Lima, V.F., Pereira, A.M.A., Almeida, W.O.
2016. Nematodes Associated with Iguana iguana (Linnaeus, 1758) (Squamata, Iguanidae) in Semi-arid Areas of Northeastern Brazil. Braz. J. Biol., 7(3), 514518.

Tiuria, R., Pratiwi, U., Tumbelaka, L.I. 2016. Parasitic Worm in Tiger (Panthera tigris) at Serulingmas Zoological Garden Banjarnegara, Bandung Zoological Garden and Indonesia Safari Park Bogor. J. Vet., $18(1), 1-10$

Vosjoli, P.D., Susan, D., Roger, K., David, B. 2012. The Green Iguana Manual. $3^{\text {rd }}$ Edition. Advance Vivarium System, p5-8.

Wilson, S.C., Carpenter, J.W. 1996. Endoparasitic Diseases of Reptiles. Seminars in Avian and Exotic Pet Medicine, 5, 64-74. 